\title{
Self Esteem, Siri', dan Perilaku Agresif pada Suku Bugis: Sisi Gelap Self Esteem Tinggi
}

\author{
Cahaya Makbul, Harmaini, Ivan Muhammad Agung \\ Fakultas Psikologi UIN Sultan Syarif Kasim Riau \\ email: harmaini@uin-suska.ac.id
}

\begin{abstract}
Abstrak
Banyak hasil penelitian tentang self esteem dan perilaku agresif tidak konsisten. Beberapa penelitian menunjukkan bahwa perilaku agresif dikaitkan oleh self esteem rendah dan sebagian lain dikaitkan dengan self esteem tinggi. Penelitian ini bertujuan untuk mengetahui hubungan self esteem dengan perilaku agresif pada suku Bugis dengan siri' sebagai variabel mediator. Subjek dalam penelitian ini berjumlah 347 orang suku Bugis. Subjek dipilih menggunakan teknik purposive sample. Berdasarkan hasil penelitian menunjukkan bahwa tidak terdapat hubungan signifikan antara self esteem dengan perilaku agresif. Berdasarkan analisis jalur diperoleh hubungan langsung antara self esteem dengan perilaku agresif sebesar -0.124 sedangkan hubungan tidak langsungnya sebesar 0,186 sehingga disimpulkan bahwa peranan langsungnya masih kalah dibandingkan dengan peran tidak langsungnya artinya siri' berperan menjadi mediator antara self esteem dengan perilaku agresif. Implikasi penelitian dibahas dalam artikel ini.
\end{abstract}

Kata kunci: self esteem, siri”, perilaku agresif, suku Bugis.

\section{Self Esteem, Siri' and Aggressive Behavior on Ethnic Bugis: The Dark Side of High Self Esteem}

\begin{abstract}
Many results of research were conducted on self esteem and aggressive behavior is not consistent. Some studies show that aggressive behavior is associated by low self esteem and others associated with high self esteem. The objective of this research was to find out the relationship of self esteem with aggressive behavior on ethnic Bugis with siri' as a mediator variable. The subjects of this research was 347 etnic Bugis. The subject of this research selected by using purposive sampling technique. The result showed that there was no significant relationship between self esteem with aggressive behavior. Based on path analysis obtained by a direct relationship between self esteem with aggressive behavior was $-0,124$ where as indirect relationship was 0,186 that concluded direct role is still less than the role of indirect, it means that siri' role as a mediator between self esteem with aggressive behavior. The implications of the research are discussed in this article.
\end{abstract}

Keywords: self esteem, siri', aggressive behavior, ethnic Bugis

\section{Pendahuluan}

Agresivitas merupakan salah satu tema yang banyak dibahas dalam penelitian psikologi sosial. Para peneliti berusaha menjelaskan hubungan atau penyebab perilaku agresif dari faktor psikologis. Salah satu faktor psikologis yang sering dikaitan dengan agresivitas adalah self esteem (Baumeister, Boden, \& Smart, 1996; Bushman \& Baumeister, 1998; Krahe, 2005; Donnellan, dkk., 2005; Buwono, 2007; Triningtyas, 2011). Self esteem merupakan kebutuhan yang sangat penting dalam kehidupan manusia, serta memainkan peran penting dalam menentukan perilaku seseorang. Self esteem memiliki dampak positif bagi emosi individu (Pyszc- zynski.dkk 2004) dan merupakan salah satu indikator sehat secara psikologis (Jordan, dkk, 2003).

Hubungan self esteem dan perilaku agresif masih menimbulkan perdebatan dikalangan peneliti (Salmivalli, 2001). Ada dua pandangan dalam memahami hubungan antara self esteem dengan agresivitas, Pertama, pandangan tradisional yang melihat bahwa terdapat hubungan negatif antara self esteem dengan agresifitas artinya semakin tinggi self esteem individu, maka semakin rendah agresiviitas (Baumeister, Boden, \& Smart, 1996). Para ahli psikologi klinis menjelasakan bahwa self esteem rendah menjadi dasar bagi orang untuk melakukan perilaku agresif (Bushman \& Baumeister, 1998). Hasil 
Penelitian Buwono (2007) mengemukakan bahwa semakin rendah self esteem, maka semakin tinggi perilaku agresif. Dijelaskan bahwa individu yang memiliki self esteem rendah cenderung menganggap dirinya orang yang tidak berguna bagi orang lain, untuk menutupi kelemahan ini, individu melakukan berbagai pembelaan diri seperti membantah hinaan orang, mengejek orang lain dan melakukan perilaku agresif lainnya supaya orang lain takut dan tak menganggap dirinya orang yang tidak mampu. Individu yang memiliki self esteem rendah akan memandang dirinya secara negatif yang dapat menimbulkan kecenderungan perilaku agresif dan perilaku antisosial lainnya (Thalib, 2002)

Kedua, pandangan yang melihat hubungan self esteem dengan agresivitas bersifat positif artinya ketika individu memiliki self esteem tinggi, semakin besar kemungkinan untuk melakukan perilaku agresif. Self esteem tinggi justru memberi peluang lebih besar untuk perilaku agresif (Baumeister, Boden, \& Smart, 1996). Penyebabnya karena orang dengan self esteem tinggi merasa lebih percaya diri, kalau berkonflik dengan orang lain dimana ia merasa akan berada di pihak yang menang, dan bahwa sebagai orang yang memiliki self esteem tinggi, ia merasa berhak untuk agresif kepada orang lain (Sarwono, 2002). Orang yang yang memiliki self esteem tinggi akan menilai dirinya positif, memiliki percaya diri bahkan cenderung narsis sehingga memiliki ego tinggi. Baumeister, Boden, \& Smart (1996) menjelaskan bahwa individu dengan self esteem tinggi lebih rentan terhadap perilaku agresif, terutama dalam menghadapi stimulus negatif (umpan balik negatif, provokasi) yang dipersepsikan sebagai ancaman terhadap self esteem mereka yang tinggi.Individu yang yang memiliki ego tinggi cenderung lebih rentan terhadap perilaku agresif (Baumeister, Boden, \& Smart, 1996: Bushman \& Baumeister, 1998)

Berdasarkan penjelasan tersebut dapat disimpulkan bahwa penelitian tentang self esteem dengan perilaku agresif telah banyak dilakukan dengan hasil yang beragam dan tidak konsisten. Penelitian ini akan difokuskan pada self esteem dan perilaku agresif pada suku Bugis. Serta dikaitkan dengan konstrak siri' pada suku bugis. Pada penelitian ini siri' diartikan sebagai salah satu konstrak yang memperantarai hubungan self esteem dan perilaku agresif pada suku Bugis.

Siri' dan Budaya

Siri' merupakan adat kebiasan yang hidup dan melembaga dalam kehidupan orang Bugis sejak dahulu hingga dewasa ini. Siri' mempunyai nilai-nilai positif dalam kehidupan bermasyarakat, namun tak dapat disangkal bahwa siri' juga mempunyai aspekaspek negatif terutama di dalam perkem- bangan dewasa ini. Kasus-kasus pidana yang terjadi banyak berlatar belakang siri', terutama dalam kasus penganiayaan dan. Definisi siri' dapat dilihat dari berbagai perspektif. Ahli bahasa melihat siri' dari segi tata bahasa dan menterjemahkan dengan "malu", siri-siri (malu-malu), verlegan, meschaamd, schroomvalling, beshame. Sedangkan ahli budaya melihat dari segi sistem sosial, dan ahli psikologi akan melihat sistem kepribadian dan sifat. Mustafa dkk (2003) mengartikan siri' menjadi dua makna yaitu aib disebabkan oleh serangan orang lain dan rasa malu yang disebabkan oleh nasib buruk yang menimpa seseorang.

Said (2006) siri' adalah pandangan hidup (lebenanschaung) yang mengandung nilai etik, pembeda manusia dan binatang dengan adanya harga diri dan kehormatan. Menurut Prof. Dr. Hamka (dalam Moein, 1994) menjelaskan pengertian siri' adalah kadang-kadang ia diberi nama malu dan dalam perkembangan bahasa Indonesia dia boleh diberi nama harga diri. Koentjaraningrat (2002) memberikan pengertian siri' merupakan daya pendorong untuk membinasakan siapa yang telah menyinggung rasa kehormatan seseorang atau daya pendorong untuk bekerja atau berusaha sebanyak mungkin $\mathrm{B}$. F. Matthes (dalam Koentjaraningrat, 2002) menterjemahkan istilah siri' merupakan malu, rasa kehormatannya tersinggung. C.H. Salam Basjah (dalam Koentjaraningrat, 2002) memberi tiga pengertian konsep siri' ialah: malu, daya pendorong untuk membinasakan siapa saja yang telah menyinggung rasa kehormatan seseorang, atau daya pendorong untuk berkerja atau berusaha sebanyak mungkin. Daeng (dalam Koro, 2006. Siri' adalah terrmasuk adat istiadat dan termasuk juga akhlak atau karakter yang dapat diartikan harga diri atau martabat diri. Rasa kesusilaan serta rasa malu yang tidak boleh dilanggar dalam suku Bugis.

Mustafa dkk (2003); Moein (1994), dan Said (2006) menjelaskan dimensi yang ada di dalam penjelasan siri' yaitu :

a. Siri sebagai harga diri yaitu kelayakan dalam kehidupan sebagai manusia yang diakui dan diperlakukan sama oleh setiap orang terhadap sesamanya

b. Siri' sebagai keteguhan hati, seseorang yang dikatakan memiliki keteguhan hati adalah seseorang yang mampu menentukan sikap sesuatu dengan kebenaran dari keteguhan hati nuraninya yang benar.

c. Moein (1994) menambahkan bahwa dimensi dalam siri' dikaitkan dengan unsur ketahanan. Yakni pantang menyerah kalah pada musuh atau pada setiap bentuk tantangan yang timbul, dalam kerangka menegakkan yang hak. 
d. Said (2006) menambahkan bahwa dimensi siri' sebagai malu atau aib.

Berdasarkan pendapat-pendapat tentang siri' tersebut di atas dapatlah disimpulkan bawah siri' adalah merupakan konstraks yang kompleks dan multidimensi. Siri' salah satu wujud kebudayaan orang bugis berupa harga diri, martabat, rasa kesusilaan, perasaan malu yang mendalam, menjadi daya pendorong atau kekuatan untuk membinasakan siapa saja yang menyinggung rasa kehormatan (harga diri, martabat diri, rasa malu, serta kesusilaan) seseorang. Dalam perspektif psikologi siri' dapat artikan sebagai ego, harga diri dan martabat. Penelitian-penelitian tentang ego atau harga diri yang dikaitan dengan perilaku agresif telah dilakukan di Eropa dan Amerika, namun dalam konteks orang Bugis Indonesia belum ada yang melakukan.

\section{Self esteem, Siri', dan Perilaku Agresif}

Perilaku agresif merupakan perilaku fisik atau lisan yang disengaja dengan maksud untuk menyakiti atau merugikan orang lain (Myers, 2012). Beberapa penelitian mengkaitan perilaku agresif dengan self esteem. Bagaimana hubungan self esteem dengan perilaku agresif? apakah individu dengan self esteem tinggi cenderung memiliki perilaku agresif rendah atau tinggi?atau tidak ada kaitan langsung antara self esteem dengan perilaku agresif?

Self esteem berperan penting dalam proses pembentukan perilaku sosial (Baumeister, dkk, 1993). Rosenberg, dkk (1995) menjelaskan bahwa individu yang memiliki self esteem tinggi akan menghormati dirinya dan mengangap dirinya sebagai individu yang berguna. Beberapa penelitian menunjukkan bahwa self esteem tinggi akan berdampak positif bagi individu seperti, kepercaan diri, komitment dan keyakinan menetapkan tujuan yang tinggi. Individu yang memiliki self esteem tinggi memiliki kemampuan yang baik dalam hal regulasi diri, kemampuan berdaptasi yang baik (Baumeister, dkk, 1993). Hal ini terjadi terjadi pada kondisi normal. Bagaimana bila kondisi spesifik misalkan adanya ancaman terhadap dirinya? apakah self esteem tinggi berdampak baik atau buruk bagi individu?

Beberapa penelitian menunjukkan bahwa self esteem tinggi memiliki sisi gelap pada diri individu jika dihadapkan pada kondisi yang berisiko. Individu yang yang memiliki self esteem tinggi akan memiliki kepercayaan diri tinggi, yang terkadang cenderung berlebihan (over) sehingga memiliki keyakinan tinggi mencapai kesuksesan. Individu seperti ini akan cenderung mengabaikan faktor risiko yang memungkinkan terjadi kegagalan (Baumeister, dkk, 1993). Beberapa peneli- tian terdahulu menunjukkan ada perbedaan dalam hubungan self esteem dan perilaku agresif. Perilku agresif lebih mudah muncul pada orang yang memiliki self esteem rendah dibandingkan tinggi, atau sebaliknya perilaku agresif lebih mudah muncul pada orang yang memilliki self esteem tinggi. Hasil penelitian Bushman, dkk., (2009) menunjukkan bahwa self esteem tinggi berkaitan dengan narsistik yang tinggi yang menghasilkan perilaku agresif yang tinggi pula. Kondisi ini muncul jika indvidu merasa terancam dirinya (ego) oleh orang lain.

Di Indonesia penelitian self esteem telah banyak dilakukan, baik dikaitkan dengan variabel positif, seperti, pengungkapan diri (Sari, dkk, 2006), efikasi diri, motivasi belajar (Novariandhini \& Latifah, 2012) maupun negative seperti, perilaku Bullying (Apsari, 2014). Sementara penelitian self esteem dan perilaku agresif pada budaya tertentu belum banyak dilakukan seperti pada suku bugis. Pada suku Bugis terdapat suatu nilai yang menjadi pegangan pada orang bugis, yaitu siri'. Koentjaraningrat (2002) memberikan pengertian siri' merupakan daya pendorong untuk membinasakan siapa yang telah menyinggung rasa kehormatan seseorang atau daya pendorong untuk bekerja atau berusaha sebanyak mungkin. Kemudian M. Natsir Said (dalam Koenjaraningrat, 2002) mengemukakan pendapatnya bahwa yang dimaksudkan dengan siri' adalah perasaan malu yang memberikan kewajiban moral untuk membunuh pihak yang melanggar adat, terutama soal-soal hubungan perkawinan.

Self esteem tidak secara langsung berkaitan dengan perilaku agresif. Individu yang yang memiliki self esteem tinggi (memandang dirinya positif, memiliki keyakinan yang kuat) tidak serta merta memunculkan perilaku agresif secara langsung (Baumeister, dkk 1996). Penelitian oleh Baummeister dan Bushman (1998) dengan menambahkan variabel narsisme. Dari hasil penelitian ini menjelaskan bahwa self esteem terbukti tidak relavan dengan perilaku agresif, namun dengan adanya kombinasi narsisme dan ancaman ego menyebabkan munculnya perilaku agresif. Hasil penelitian ini dapat disimpulkan bahwa self esteem tidak secara langsung mempengaruhi perilaku agresif namun ada faktor lain yang berpengaruh dalam mempengaruhi hubungan self esteem dengan perilaku agresif.

Demikian juga yang yang terjadi pada suku Bugis, hubungan self esteem dengan perilaku agresif bersifat tidak langsung, artinya ada variabel lain dalam hal ini siri' sebagai perantara memunculkan perilaku agresif. Individu yang memiliki self esteem tinggi akan cenderung menilai dirinya positif dan memiliki siri' yang tinggi (a), individu yang memiliki 
siri' tinggi adalah orang yang memiliki prinsip kuat, berusaha menjaga nilai dan kehormatan dirinya. Individu yang berpegang pada nilai siri' akan berusaha menjaga self esteem dan rasa malu (Said, 2006; Mustafa dkk., 2003). Indvidu yang memiliki siri' tinggi akan lebih rentan untuk berperilaku agresif. Ketika individu dihadapkan pada situasi sosial yang mengancam diri, individu yang memiliki siri' tinggi cenderung lebih mudah memunculkan perilaku agresif dibandingkan yang memiliki siri' rendah (lihat bagan 1).

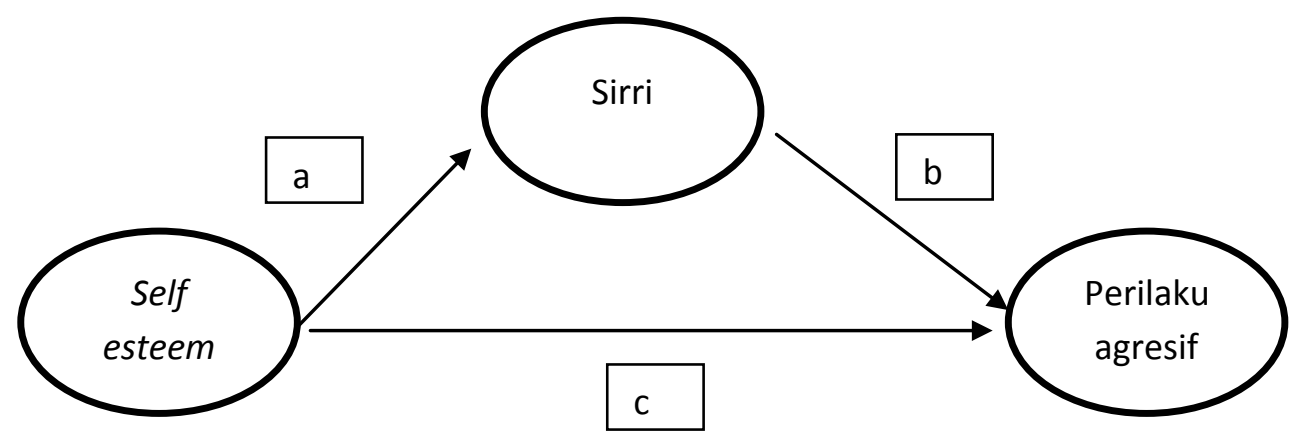

Bagan.1 Siri' Sebagai Mediator Antara Self Esteem dan Perilaku

Dari penjelasan diatas, dapat dikatakan bahwa adanya perbedaan konsep dalam penjelasan hubungan antara self esteem dan siri' dengan perilaku agresif. Dalam penelitian ini, peneliti akan melakukan penelitian untuk mengetahui hubungan self esteem terhadap perilaku agresif dengan siri' sebagai variabel mediator dalam suku Bugis. Adapun hipotesis yang diajukan adalah siri' sebagai mediator antara self esteem dengan perilaku agresif.

\section{Metode}

\section{Partisipan}

Jumlah partisipan dalam penelitian ini sebanyak 347 orang suku Bugis dengan rentang usia 30-60 tahun (168 pria dan 179 wanita) yang berasal dari penduduk Desa Pulau Kijang Kecamatan Reteh Kabupaten Indragiri Hilir provinsi Riau. Tingkat pendidkan partisipan terdapat 28 orang $(8,07 \%)$ subjek penelitian yang tidak sekolah, sebanyak 134 orang $(39,77 \%)$ subjek berpendidikan SD, $78(22,48$ $\%$ ) subjek berpendidikan SMP, dan 103 orang $(29,68 \%)$ subjek berpendidikan SMA

\section{Pengukuran}

Self esteem. Pengukuran dalam penelitian ini dengan menggunakan Self Esteem Scale (SES) Rosenberg (1995) yang terdiri dari dua dimensi yaitu, dimensi penerimaan diri dan dimensi penghormatan diri yang dimodifikasi dengan 15 jumlah aitem dengan dengan reliabilitas $(\alpha)$ sebesar 0,796 . Setelah dilakukan uji coba, dari 15 aitem alat ukur self esteem, terdapat 6 aitem yang gugur dan 9 aitem ydang dapat digunakan.

Siri". Pengukurannya menggunakan skala siri' yang dibuat sendiri oleh penulis berdasarkan teori Mustafa dkk., (2003), Moien (1994), dan Said (2006) yang terdiri dari empat dimensi, yaitu harga diri, keteguhan hati, ketahanan dan malu jumlah aitem sebanyak 35 aitem dengan reliabilitas diperoleh sebesar 0,910 . Setelah dilakukan trayout ada 13 aitem gugur dan 22 aitem yang dapat digunakan dalam penelitian. Agresivitas, diukur dengan skala perilaku agresif Buss-Perry Scale (dalam Nashori, 2008) yang dimodifikasi dengan 29 jumlah aitem. Jumlah aitem sebanyak 29 , setelah tray out tinggal 23 dan 6 aitem yang dinyatakan gugur dengan reliabilitas sebesar 0,880. Skala ini disusun berdasarkan skala Likert, dengan memodifikasi menjadi 5 pilihan jawaban yaitu sangat sesuai (SS), sesuai (S), netral (N), tidak sesuai (TS), dan sangat tidak sesuai (STS) yang terdiri dari pernyataan favorabel dan unfavorabel.

\section{Analisis Data}

Analisis data yang digunakan pada penelitian ini dengan menggunakan teknik product moment dan analisis jalur. Dalam penelitian ini, variabel yang diteliti adalah tiga variabel, dengan satu variabel bebas, satu variabel mediator, dan satu variabel terikat. Analisis data menggunakan bantuan Program SPSS 16 for Windows dan AMOS version 5 .

\section{Hasil}

Tabel 1 menunjukkan bahwa nilai signifikansi koefisien jalur pada variabel self esteem dengan siri' adalah 0,000 , berarti signifikansi berada di level $p<0,01$ artinya hubungan kedua variabel tersebut sangat signifikan, dengan nilai (r) 0,399 artinya ada hubungan positif antara self esteem dengan siri'. Pada variabel siri' dengan perilaku agresif memiliki signifikansi koefisien 0,027 berarti signifikansi berada dilevel $p<0,05$ dengan nilai $(r) 0,119$ artinya ada hubungan positif antara siri' dengan perilaku agresif. Sementara pada variabel self esteem dengan perilaku agresif me- 
miliki signifikansi koefisien 0,206 yang berarti $p>0,05$ dan nilai $(r)-0,068$ dengan demikian

tidak ada hubungan antara self esteem dengan perilaku agresif.

Tabel. 1 Interkorelasi Variabel Penelitian

\begin{tabular}{llll}
\hline Variabel & 1 & 2 & 3 \\
\hline Self esteem & & $0,399^{* *}$ & $-0,068$ \\
Siri' & $0,399^{* *}$ & & $0,119^{*}$ \\
Agresifitas & $-0,068$ & $0,119^{*}$ & \\
\hline Ket: ${ }^{* *} p<0,01 ;{ }^{*} p<0,05$ & &
\end{tabular}

Analisis Mediasi

Analisis ini menggunakan analisis jalur dengan bantuan AMOS version 5 untuk melihat hubungan antara self esteem $(X)$ dengan perilaku agresif $(\mathrm{Y})$ dengan hubungan keduanya dimediatori oleh siri' (M). Baron dan Kenny (1986), menjelaskan bahwa dalam analisis jalur harus terlebih dahulu melihat signifikan hubungan antara variabel $X$ dengan $\mathrm{Y}$, dan hubungan $\mathrm{X}$ dengan $\mathrm{M}$, serta hubungan $\mathrm{M}$ dan $\mathrm{Y}$. Untuk melihat fungsi variabel $M$ maka saharusnya variabel $X$ dengan
$Y$ tidak memiliki hubungan yang atau memiliki hubungan yang lemah (lihat tabel 1). Berdasarkan hasil analisis korelasi bivariate diketahui bahwa variabel $\mathrm{X}$ dan $\mathrm{M}$ memiliki hubungan yang signifikan, diketahui pula variabel $\mathrm{M}$ dan $\mathrm{Y}$ memilki hubungan yang signifikan, sementara variabel $X$ dan $Y$ tidak memiliki hubungan yang signifikan. Maka dari itu, selanjutnya akan dilihat hubungan variable $X$ dan $Y$ melalui variabel $M$ sebagai variabel mediator melalui analisis jalur.

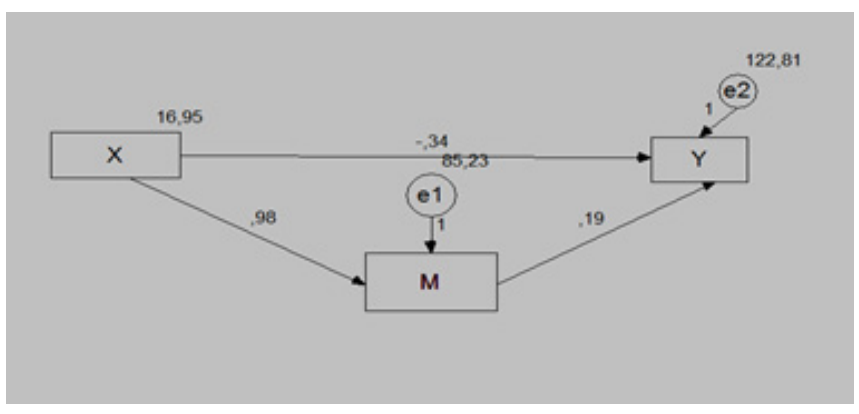

Bagan 2. Hasil Analsiis mediasi menggunakan analsiis jalur

Tabel 2. Standardized Regression Weights:

(Group number 1 - Default model)

\begin{tabular}{ll}
\hline Variabel & Estimate \\
\hline $\mathrm{M}<---\mathrm{X}$ & 0,399 \\
$\mathrm{Y}<---\mathrm{M}$ & 0,171 \\
$\mathrm{Y}<---\mathrm{X}$ & $-0,124$ \\
\hline
\end{tabular}

Dari tabel 2 dapat dilihat bahwa variabel $X$ memiliki hubungan positif terhadap variabel $\mathrm{M}$, yaitu sebesar 0.399. Variabel M memiliki hubungan positif terhadap variabel $Y$ sebe- sar 0.171 , dan Variabel $X$ memiliki hubungan negatif terhadap variabel $Y$, yaitu sebesar -0.124 .

Tabel 3 Indirect Effects (Group number 1 - Default model)

\begin{tabular}{lll}
\hline Variabel & $\mathrm{X}$ & $\mathrm{M}$ \\
\hline $\mathrm{M}$ &, 000 &, 000 \\
$\mathrm{Y}$ &, 186 &, 000 \\
\hline
\end{tabular}


Berdasarkan tabel 3 di atas dapat diketahui bahwa peranan variabel $\mathrm{M}$ sebagai mediator dapat dilihat pada bagian peranan tidak langsung (indirect effect). Dari tabel di atas didapat bahwa peranan tidak langsung variabel $M$ dalam hubungan variabel $X$ dengan variabel $Y$ adalah sebesar 0.186 . hubungan langsung Variabel $X$ dengan variabel $Y$, yaitu sebesar -0.124 , sehingga dapat disimpulkan bahwa peranan langsungnya masih kalah dibanding dengan peranan tidak langsungnya, artinya siri' menjadi variabel mediator antara self esteem dengan perilaku agresif.

\section{Pembahasan}

Penelitian ini bertujuan untuk melihat hubungan self esteem, siri' dan perilaku agresif pada suku Bugis. Dari hasil penelitian yang telah dilakukan diketahui bahwa tidak ada hubungan antara self esteem dengan perilaku agresif artinya individu yang memiliki self esteem tinggi atau rendah tidak berhubungan secara langsung dengan perilaku agresif. Hasil ini sesuai dengan penelitian Mawaddah (2015) yang menyatakan bahwa tidak ada hubungan signifikan antara self esteem dengan perilaku agresif. Sementara ada hubungan positif antara self esteem dengan siri' artinya semakin tinggi self esteem maka semakin tinggi siri' yang dimiliki orang Bugis begitu pula sebaliknya semakin rendah self esteem maka semakin rendah pula siri' yang dimiliki oleh orang Bugis. Penelitian ini juga menunjukkan bahwa ada hubungan positif antara siri' dengan perilaku agresif. Artinya semakin tinggi siri' yang dimiliki orang Bugis maka semakin tinggi pula perilaku agresif pada orang Bugis.

Secara umum menunjukkan bahwa self esteem tidak secara langsung berhubungan dengan perilaku agresif. Namun terdapat faktor lain dalam hubungan self esteem dengan perilaku agresif. Oleh karena itu, dalam penelitian ini menggunakan siri' sebagai variabel mediator dalam hubungan self esteem dengan perilaku agresif. Dari hasil analisis yang telah dilakukan diketahui bahwa siri' berperan sebagai mediator dalam hubungan self esteem dan perilaku agresif. Artinya hipotesis pada penelitian ini diterima. Hal yang hampir senada dikemukakan oleh Bushman, \& Baumeister (1998) yang menyatakan bahwa self esteem terbukti tidak relavan dengan perilaku agresif, namun dengan adanya kombinasi narsisme dan ancaman ego menyebabkan perilaku agresif. Individu dengan self esteem tinggi cenderung memiliki ego yang tinggi segingga lebih besar melakukan tindakan agresif. Dari hasil penelitian ini dapat disimpulkan bahwa self esteem tidak secara langsung mempengaruhi perilaku agresif namun ada varabel perantara antara self es- teem dan perilaku agresif, yaitu siri'.

Self esteem memiliki peran penting dalam kehidupan manusia. Self esteem tinggi memiliki efek positif bagi manusia, seperti perasaan positif (Pyszczynski.dkk, 2004), namun disisi lain self esteem tinggi memiliki sisi gelap, yaitu keinginan untuk selalu menjaga self esteem dari ancaman orang lain sehingga ego atau harga dirinya tetap menjadi tinggi. Menurut Pyszczynski.dkk, (2004) setiap individu ingin memiliki self esteem tinggi dan berusaha menjaganya atau mempertahankan ketika ada situasi yang mengancam. Individu dengan self esteem yang tinggi akan menilai dirinya orang yang berharga, percaya diri, serta memiliki keyakinan untuk dapat menyelesaikan segala tantangan. Individu dengan self esteem tinggi cenderung lebih percaya diri ketika berhadapan dengan risiko, seperti perkelahian (Sallmivalli, 2001)

Self esteem tinggi secara langsung atau tidak langsung meningkatkan persepsi positif terhadap dirinya bahkan cenderung meningkatkan narsistik (Bushman, dkk., 2009). Hal tersebut secara langsung meningkatkan harga diri (martabat) seseorang yang dalam hal ini disebut dengan siri'. Hasil penelitian membuktikan bahwa self esteem berhubunga positif dengan siri'. Indvidu yang memiliki self esteem tinggi akan memiliki siri' yang tinggi. Individu yang memiliki nilai siri' tinggi dicirikan dengan orang yang memiliki prinsip kuat, harga diri tinggi, dan menjunjung nilai-nilai yang melekat pada siri' tersebut.

Hasil penelitian ini menunjukkan bahwa indvidu yang memiliki atau menganut siri' tinggi cenderung memiliki perilaku agresif yang lebih tinggi. Individu yang memiliki nilai siri' tinggi cenderung memiliki atau memegang nilai-nilai kehormatan yang tinggi, dan cenderung memiliki prinsip (ego) yang kuat. Siri' merupakan hal yang penting bagi orang Bugis karena merupakan salah satu wujud kebudayaan orang bugis berupa harga diri, martabat, rasa kesusilaan, perasaan malu yang mendalam, menjadi daya pendorong atau kekuatan untuk membinasakan siapa saja yang menyinggung rasa kehormatan (harga diri martabat diri, rasa malu, serta kesusilaan) seseorang (Yusuf, 2008; Mustafa, dkk 2003). Kondisi tersebut tentunya lebih mudah memunculkan perilaku agresif dibandingan orang yang memiliki nilai siri' yang rendah. Misalkan, ketika individu yang memiliki siri' tinggi berhadapan pada situasi social yang mengancam atau diperlakukan negatif (dihina), maka akan indvidu tersebut akan mudah melakukan perilaku agresif (verbal atau fisik) terhadap orang tersebut dbandingkan orang yang memiliki siri' rendah. Baumeister dan Boden (1998) yang menyatakan bahwa individu-individu dengan self esteem tinggi lebih rentan terhadap perilaku agresif, terutama 
dalam menghadapi stimulasi negatif (umpan balik negatif, provokasi) yang dipersepsi sebagai ancaman terhadap self esteem mereka yang tinggi. Indvidu berusaha tetap menjaga self esteem tinggi dan tetap menjunjung siri' (kehormatan) yang dimiliki.

Secara umum hasil penelitian ini menunjukkan bahwa self esstem dapat meningkatkan siri', sehingga siri' meningkatkan perluang untuk berperilaku agresif. Namun hal yang patut dicatat adalah bukan berarti orang yang memiliki siri' tinggi mempengaruhi terbentuknya perilaku agresif. Siri' merupakan salah satu nilai positif yang meliputi harga diri, martabat dan kehormatan individu dalam memegang nilai-nilai yang ada dalam budaya Bugis. Perilaku agressf akan muncul melibatkan banyak faktor baik internal dan eksternal. Perilaku agresif akan lebih mudah muncul jika individu berada pada situasi tertentu seperti, stuasi yang mengancam terhadap ego, dan kehormatan diri (Baumeister, dkk., 1996; Bushman, \& Baumeister, 1998, Salmivalli, 2001). Dengan demikian indvidu yang memiliki siri' tinggi akan mudah melakukan perlaku agresif jika dihadapkan pada situasi yang dipersepsikan membuat drinya terancam atau yang tidak menyenangkan.Beberapa keterbatasan dalam penelitian, pertama, jumlah dan variasi subjek belum mewakili data demografi yang ada sehingga belum dapat menggambarkan secara keseluruhan. Kedua, eksplorasi konsep siri' belum dilakukan secara mendalam karena keterbatasan referensi khususnya dalam pengukuran siri' tersebut, ketiga, pengujian hubungan self esteem, siri', dengan perilaku perilaku agresif tidak dilakukan pada situasi yang spesifik dan hanya secara umum.

\section{Kesimpulan}

Berdasarkan penjelasan di atas, diketahui dari penelitian ini bahwa self esteem tidak memiliki hubungan secara langsung dengan perilaku agresif. Namun siri' berperan sabagai mediator hubungan self esteem dengan perilaku agresif. Self esteem berkontribusi pada siri' yang dimiliki oleh orang Bugis artinya tinggi atau rendahnya self esteem berhubungan positif terhadap siri' yang dimiliki orang Bugis. sementara siri' yang dimiliki oleh orang Bugis berkontribusi pada munculnya perilaku agresif, artinya tinggi atau rendahnya siri' yang dimiliki oleh orang Bugis berdampak pada kemunculan perilaku agresif. Akhirnya, penelitian- penelitian selama ini yang mengkaitkan self esteem dengan variabel negatif (seperti, bullying, agresif) lainnya perlu dikaji lagi:apakah self esteem memiliki hubungan langsung (positif atau negative) atau tidak langsung, seperti dalam penelitian ini yang menunjukkan ternyata self esteem tinggi akan meningkatkan siri' (kehormatan) individu dan cenderung membuat orang lebih agresif. Selain itu perlunya pengujian hubungan self esteem, siri', dengan perilaku perilaku agresif pada situasi alami atau eksperimen yang melibatkan situasi-situasi tertentu yang mempengaruhi munculnya perilaku agresif.

\section{Daftar Pustaka}

Alsa, A. (2007). Pendekatan Kuantitatif \& Kualitatif Serta Kombinasinya Dalam Penelitian Psikologi. Yogyakarta: Pustaka Pelajar.

Apsari, F (2014). Hubungan Antara Self esteem Dan Disiplin Sekolah Dengan Perilaku Bullying Pada Remaja. Tesis tidak dipublikasikan. Program Magister Sains Psikologi Universitas Muhammadiyah Surakarta.

Baron, R. M., \& Kenny, D. A. (1986). The moderator-mediator variable distinction in social psychological research: Conceptual, strategic, and statistical considerations. Journal of Personality of Social Psychology, 51, 1173-1182.

Baron, R. A., \& Byrne, (2005). Psikologi Sosial Jilid 2. Alih Bahasa: Ratna Djuwita. Edisi kesepuluh. Jakarta: Erlangga.

Baumeister, R.F , Heatherton, T.F \& Tice. D.M (1993). When Ego Threats Lead to Self-Regulation Failure: Negative Consequences of High Self-Esteem. Journal of Personality and Social Psychology. 64, 1,141-156

Baumeister, R.F., Smart, L., \& Boden, J. M. (1996). Relation of Theatened Egoistm to Violence and Aggression: The dark side of High Self-Esteem. Psychological Review, 103, 5-33.

Bushman, B. J. \& Baumeister. R. F. (1998). Threatened Egotism, Narcissism, Self-Esteem, and Direct and Displaced Aggression: Does SelfLove or Self-Hate Lead to Violence?. Journal of Personality and Social Psychology. 75, (1), 219-229.

Bushman, B.J, Baumeister,, R.F, Thomaes, S, Ryu, E, Begeer,S \& West, S.G. (2009). Looking Again, and Harder, for a Link Between Low Self-Esteem and Aggression. Journal of Personality 77(2), 1-21.

Buwono, A S. (2007). Perilaku Agresif Ditinjau Dari Self esteem Pada Remaja yang Dibina Balai Permasyarakatan (BAP AS) Semararang. Skripsi. Perpustakaan Universitas Katolik Soegijapranata Semarang.

Dayakisni, T. \& Hudaniah. (2006). Psikologi Sosial. Malang: UMM Press. 
Donnellan, M.B, Trzesniewski, K.H, Robins, R.W, Moffitt T.E, \& Caspi, A (2005) Low self esteem is Related Agression, Antisocial Behavior, and Deliquency. Psycholocial Science, 16(4),328-335.

Jordan, C.H, Spencer, S. J, Zanna, M. P, Hoshino-Browne, E \& Correll, J (2003). Secure and Defensive High SelfEsteem. Journal of Personality and Social Psychology. 85,(5), 969-978

Koentaraningrat, (2002). Manusia dan Kebudayaan di Indonesia. Jakarta: Djambatan.

Koro, N. (2006). Ayam Jantan Tanah Daeng siri' \& passé. Jakarta: Ajuara.

Krahe, B. (2005). Perilaku Agresif. Yogyakarta: Pustaka Pelajar.

Mawaddah, N, Ahsan, \& Supriati, L. (2015). Pengaruh Terapi Social Skills Training Terhadap Self esteem Dan Perilaku Agresif Remaja Di SMK Pertiwi Mojokerto Dengan Pendekatan Model Interpersonal Peplau. The Indonesian Journal Of Health Science, 6, (1) 5262.

Mercer, J \& Clayton, D. (2012). Psikologi Sosial. Jakarta: Erlangga.

Moein. M.G, A. (1994). Sirik Na Pacce. Ujung Pandang: Yayasan Makassar Press.

Mustafa, M. Y., A. Wanau T. \& Nasyaruddin. (2003). Siri' dan Passe' Self esteem Orang Bugis, Makassar, Mandar, Toraja. Makassar: Yayasan adikarya IKAPI dan The Ford Foundation.

Myers, D. G. (2012). Psikologi Sosial. Jakarta Selatan: Salemba Humanika.

Nashori, F. (2008). Psikologi Sosial Islam. Bandung: Refika Aditama

Novariandhini, D. A \& Latifah, M (2014) Self esteem, Efikasi diri, Motivasi Belajar dan Prestasi Akademik pada Siswa SMA pada berbagai Model Pembelajaran. Jurnal ilmu Keluarga dan Konseling, 5(2), 138-146.

Pyszczynski, T, Greenberg, J, Solomon, S, Arndt, J \& Schimel, J. (2004). Why Do People Need Self-Esteem? A
Theoretical and Empirical Review. Psychological Bulletin 130,(3), 435468.

Rosenberg, M, Schooler, C, Schoenbach, C \& Rosenberg, F (1995). Global SelfEsteem and Specific Self-Esteem: Different Concepts, Different Outcomes. American Sociological Review. 60, (1), 141-156.

Said, H.M. N. (2006). Siri' dan Tertib Sosial. Makassar: Pustaka Nusantara Padaidi.

Salmivalli, C. (2001). Feeling good about one self, being bad to others? Remark on Self Esteem, Hostility, and Aggressive behavior. Aggression and violent Behavior, 6, 375-393.

Sari, R. P, Rejeki ,T \& Mujab, A M. (2006). Pengungkapan Diri Mahasiswa Tahun Pertama Universitas Diponegoro Ditinjau Dari Jenis Kelamin dan Self esteem. Jurnal Psikologi Universitas Diponegoro 3 (2) 11-25.

Sarwono, W. Sarlito. (2002). Psikologi Sosial: Individu dan Teori-Teori Psikologi Sosial Edisi 3. Jakarta: Balai Pustaka.

Sarwono, W. Sarlito \& Meinarno, E. A. (2009). Psikologi Sosial Jakarta: Salemba Humanika.

Sarwono, J. (2007) Analisis Jalur untuk Riset Bisnis dengan SPSS. Yogyakarta: ANDI.

Taylor, Shelley E., Letitia Anne Peplau., \& David O. Sears. (2009). Psikologi Sosial (12rd ed). Jakarta:Kencana.

Thalib, S. B. (2002). Dinamika sosial psikologis perilaku kekerasan siswa. Arkhe, Th VII, No 2. Hal 80-90.

Triningtyas, D. A., Suroso., \& Herlan Pratikto. (2011). Hubungan Antara Konformitas dan Self esteem Dengan Kecenderungan Agresivitas Remaja.

Yusuf, M. D. (2008). Orang Bugis di Semenanjung Melayu. Pekanbaru: KKSS 